Sains Malaysiana 50(10)(2021): 3003-3014

http://doi.org/10.17576/jsm-2021-5010-14

\title{
Hydrogenated Liquid Natural Rubber for Compatibility Enhancement of Poly (lactic acid) and Natural Rubber Blends
}

(Getah Asli Cecair Terhidrogenasi untuk Peningkatan Keserasian Campuran Poli(asid laktik) dan Getah Asli)

\author{
Mohamad Shahrul FizReE Idris, Nurfarhana Mohd MustafFARIZAN \& Siti fairus M. YusofF*
}

\begin{abstract}
Non-catalytic hydrogenation of liquid natural rubber (LNR) via thermal decomposition of 2,4,6-trimethylbenzenesulfonylhydrazide (MSH) is reported in this study. Parameter studies of the hydrogenation reaction were performed by utilizing the combination of response surface methodology and central composite rotatable design (RSM/CCRD). The effects of each variable and the interaction between two variables (i.e. the MSH:LNR weight ratio and reaction time) were studied. Statistical analysis showed that the reaction time had significantly affected the hydrogenation percentage. A reduced quadratic model equation with the coefficient of determination $\left(R^{2}\right)$ value of 0.9875 was developed. The optimized condition as predicted by the software was compared with the experimental data, which deviated in only 0.67 , hence indicating that this model was reliable and able to predict the hydrogenation percentage accurately. Fourier-transform infrared (FTIR) and nuclear magnetic resonance (NMR) spectroscopies were used to characterize the microstructure of LNR and hydrogenated liquid natural rubber (HLNR). HLNR was then used as compatibilizer to improve the miscibility of poly(lactic acid)/natural rubber blends. With an addition of $4 \%$ HLNR, the tensile strength and impact strength of the blends were slightly improved.
\end{abstract}

Keywords: Hydrogenation; liquid natural rubber (LNR); surface optimization; 2, 4,6-trimethylbenzenesulfonylhydrazide (MSH)

ABSTRAK

Penghidrogenan tanpa mangkin getah asli cair (LNR) melalui penguraian terma 2,4,6-trimetilbenzenasulfonilhidrazida (MSH) dilaporkan dalam kajian ini. Kajian parameter tindak balas penghidrogenan dilakukan dengan menggunakan gabungan kaedah rangsangan permukaan dan reka bentuk komposit putaran tengah (RSM/CCRD). Kesan setiap pemboleh ubah dan interaksi antara dua pemboleh ubah (iaitu nisbah berat MSH: LNR dan masa tindak balas) dikaji. Analisis statistik menunjukkan bahawa masa tindak balas telah mempengaruhi peratusan penghidrogenan secara signifikan. Persamaan model kuadratik dengan nilai pekali penentuan $\left(R^{2}\right) 0.9875$ diperoleh. Keadaan yang dioptimumkan seperti yang diramalkan oleh perisian dibandingkan dengan data uji kaji, yang menyimpang hanya 0.67, sehingga menunjukkan bahawa model ini boleh dipercayai dan dapat meramalkan peratusan penghidrogenan dengan tepat. Spektroskopi inframerah transformasi Fourier (FTIR) dan resonans magnetik nuklear (NMR) digunakan untuk mencirikan struktur mikro LNR dan getah asli cecair terhidrogen (HLNR). HLNR kemudian digunakan sebagai pengserasi untuk meningkatkan keserasian campuran poli(asid laktik)/getah asli. Dengan penambahan HLNR 4\%, kekuatan tegangan dan kekuatan hentaman campuran telah meningkat sedikit.

Kata kunci: Getah cecair asli (LNR); penghidrogenan; pengoptimuman permukaan; 2,4,6-trimetilbenzenasulfonilhidrazida (MSH)

\section{INTRODUCTION}

Natural rubber (NR) is a biosynthesized and biodegradable rubber from Hevea brasiliensis. It has attracted scientific and industrial interest due to its outstanding properties including high elastic properties and mechanical strength. Numerous researchers have reported on the modification of NR in order to extend its application (Kawahara et al. 2003; Radhakrishnan Nair et al. 2019; Zhong et al. 1999). Liquid natural rubber (LNR) is a reduced form of NR that is prepared from photodegradation process. It has similar polyisoprene microstructure as NR, but with lower molecular weight. Unlike NR, LNR is in liquid form that can be mixed easily due to its low viscosity. LNR as starting material requires 
less energy to initiate the chemical reaction progress (Azhar et al. 2017; Nor \& Ebdon 1998).

Chemical modifications of NR/LNR produce new materials with a wide range of applications. At present, various modifications on NR/LNR have been studied and commercialized. Some examples of commercially modified NR are epoxidized NR (ENR) and chlorinated NR (CNR) (Hamzah et al. 2012; Sen et al. 2001). Hydrogenated NR (HNR) has gained much attention from researchers and manufacturers as it improves the thermal properties of NR. HNR can be prepared either from catalytic or non-catalytic hydrogenation. However, non-catalytic hydrogenation is preferred because it demands simple laboratory set up and low preparation cost (Idris et al. 2019). Researchers have found that hydrogenated liquid natural rubber (HLNR) also exhibits high resistance towards thermal degradation (Mahittikul et al. 2007). Azhar et al. (2015) has performed thermal analysis on LNR and HLNR to observe their degradation behavior. Based on the results obtained, the degradation temperature for both LNR and HLNR (95.9\%) was at $374{ }^{\circ} \mathrm{C}$ and $462{ }^{\circ} \mathrm{C}$, respectively. Hydrogenation has been proven to increase the thermal stability of LNR. $p$-toluenesulfonyl hydrazide (TSH) and 2,4,6-trimethylbenzenesulfonylhydrazide (MSH) are commonly used to hydrogenate the unsaturated double bonds of LNR (Azhar et al. 2015; Jamaluddin et al. 2016; Rasid et al. 2016). However, the thermolysis rate of MSH was 24 times higher and at relatively lower temperature than TSH (Cusack et al. 1976). It is reasonable to assume that the hydrogenation using MSH is more efficient because the diimide molecules needed for hydrogenation can be generated in a short time.

Recently, response surface methodology (RSM) has been widely used for designation and optimization of experimental design (Mohamad et al. 2014; Razak et al. 2015). It is a collection of mathematical and statistical technique that evaluates the relationship between different parameters and response variables. This method suggests the optimum conditions of reaction while considering the interaction effects among the independent variables. The main advantage of RSM is the reduced number of experimental runs needed to provide sufficient information for statistically acceptable results (Gunawan et al. 2005).

In this study, HLNR was prepared by hydrogenation process using MSH as diimide source. The optimization of the hydrogenation percentage was performed by RSM/ CCRD based on MSH:LNR weight ratio and reaction time. The optimized HLNR was characterized using Fouriertransform infrared (FTIR) and nuclear magnetic resonance
(NMR) spectroscopies. Next, the capability of HLNR as a filler or compatibilizer in blending between bio-based polymer; poly(lactic acid) (PLA) and NR, were studied. Different compositions of LNR and HLNR were used to improve the mechanical properties of the PLA/NR blends. Morphological properties of blends were also studied and discussed.

\section{MATERIALS AND METHODS}

\section{MATERIALS}

In this work, NR was supplied from the Malaysian Rubber Board. PLA was produced by ESUN, China. AR grade of Xylene ( $>99 \%)$, toluene ( $>99 \%)$, ethanol (95\%), and methanol ( $>99.8 \%$ ) were provided by R\&M Chemicals. Methylene blue ( $\geq 95 \%$ ), rose bengal (95\%) and 2,4,6-trimethylbenzenesulfonylhydrazide (MSH) (97\%) were supplied from Sigma Aldrich.

\section{HYDROGENATION OF LNR}

LNR with $25 \%$ of dry rubber content was prepared (Abdullah 1996). LNR was then dried in a vacuum oven for $24 \mathrm{~h}$. Hydrogenation of LNR was carried out in a 250 $\mathrm{mL}$ round bottom flask, equipped with a reflux condenser and a magnetic stirrer. Different amounts of MSH were added into the flask with a fixed weight of dried LNR $(0.5$ g) in the range of ratio $0.5: 1$ to $1: 1$ for MSH:LNR. Each mixture was stirred at $650 \mathrm{rpm}$ and the reaction temperature was fixed at $100{ }^{\circ} \mathrm{C}$. The reaction was conducted with different reaction times (20-60 $\mathrm{min})$. After reaction has completed, reaction mixture was filtered and coagulated in ethanol to remove residual MSH. Coagulated product was dried in a vacuum oven for at least $12 \mathrm{~h}$. The reaction scheme of hydrogenation of LNR using MSH is shown in Scheme 1.

\section{PREPARATION OF PLA/NR BLENDS}

Generally, all materials were mixed with an internal mixer (Thermo Haake Rheomix) at $170{ }^{\circ} \mathrm{C}$ and rotor speed of $60 \mathrm{rpm}$ for $15 \mathrm{~min}$. First, NR was loaded in the internal mixer for $5 \mathrm{~min}$. After that, PLA was added into the mixer. LNR or HLNR was added during the last $5 \mathrm{~min}$ of mixing. After mixing, samples for tensile (ASTM D412) and impact (ASTM D256) analysis were molded and prepared by compression molding at $170{ }^{\circ} \mathrm{C}$ for $10 \mathrm{~min}$.

\section{INSTRUMENTATION AND CHARACTERIZATION}

Fourier-transform infrared (FTIR) and nuclear magnetic resonance (NMR) spectroscopies were used to identify 
the structure of the products. The structure of HLNR was confirmed by monitoring any changes in the main characterization bands that might have been induced after hydrogenation. Agilent Cary 630 FTIR was employed and the samples were analyzed in transmittance mode within the range $600-4000 \mathrm{~cm}^{-1}$. NMR spectroscopy was utilized to examine the microstructure of LNR and HLNR. Samples were dissolved in $\mathrm{CDCl}_{3}$ for measurement with the Nuclear Magnetic Resonance $400 \mathrm{MHz}$ (Bruker $400 \mathrm{MHz}$ AVANCE III HD). Integration of signals from proton NMR $\left({ }^{1} \mathrm{H}\right.$ NMR) spectrum was used to calculate the percentage of hydrogenation of HLNR (Jamaluddin et al. 2016). The hydrogenation percentage of HLNR was calculated using (1).

$$
\text { Degree of olefin conversion }(\%)=\frac{100(A-7 B)}{A+3 B}
$$

where $\mathrm{A}$ is the peak area of paraffin proton $(0.8-2.1 \mathrm{ppm})$, and $\mathrm{B}$ is the peak area of olefinic protons $(5.1 \mathrm{ppm})$. The equation was derived from Kongparakul et al. (2011).

The tensile properties of the blend samples were examined using Universal Testing Machine (Instron/5566) at $5 \mathrm{~mm} / \mathrm{min}$ with $1 \mathrm{kN}$ load cell. The notched Izod impact test was performed using an impact testing machine (Tinius Olsen/Model IT504/Model 104). It was used to evaluate the toughness of the samples. For morphology study, scanning electron microscope (SEM, Zeis Supra 55vp) was used to study the morphology of the solid blend products.

\section{EXPERIMENTAL DESIGN}

Important variables on the hydrogenation of LNR using MSH were optimized using the RSM/CCRD approach. The MSH:LNR weight ratio $(A)$ and reaction time $(B)$ were the independent variables used in this study. The ranges and levels of the chosen variables are shown in Table 1.

Two factors with total of 13 experimental runs were suggested by RSM/CCRD using Design Expert Software 7.1.5. Three-dimensional (3D) response surface modeling and optimum reaction condition were achieved with the assistance of this software. Analysis of variance (ANOVA) was used to analyze the significant variances between independent variables to the output data. Validation process of the suggested model and optimization of the response were conducted. The efficiency of the model was verified by performing the suggested experiments and comparing the outputs with the predicted results.

TABLE 1. Experimental range and level of the respective independent variable

\begin{tabular}{lccccc}
\hline & \multicolumn{5}{c}{ Coded level } \\
\cline { 2 - 5 } Variables/factors & -2 & -1 & 0 & +1 & +2 \\
\hline MSH:LNR weight ratio, $A$ & 0.50 & 0.57 & 0.75 & 0.93 & 1.00 \\
Reaction time, $B(\mathrm{~min})$ & 20.00 & 25.86 & 40.00 & 54.14 & 60.00 \\
\hline
\end{tabular}

\section{RESULTS AND DISCUSSION}

\section{MODEL FITTING AND STATISTICAL TECHNIQUE}

Response surface modeling comprising a five-level-twofactor was conducted to get the optimum conditions of hydrogenation. The experimental data in Table 2 was analyzed by Design Expert software in order to be fitted with the predicted data. Figure 1 shows the comparison between the hydrogenation percentages obtained through experiments and prediction by (2). It can be seen that the actual values seemly correlated to the predicted values.

From the software, fitted equation model was constructed as shown:
Yield of monosaccharides $(\mathrm{mg} / \mathrm{g}$ substrate $)=\frac{\mathrm{M}_{\text {mono }}(\mathrm{mg} / \mathrm{L}) \times \mathrm{V}_{\mathrm{aq}}(\mathrm{L})}{\mathrm{W}_{\text {substrate }}(\mathrm{g})}$

where $A$ is the weight ratio of MSH:LNR and $B$ is the reaction time. The main linear $(A, B)$, quadratic $\left(A^{2}, B^{2}\right)$ and interaction $(A B)$ effects represented the coefficients in the equation. It was found that the reduced-quadratic model fit the experimental data well. The ANOVA of the hydrogenation percentage response (Table 3 ) indicated that this model was highly significant with the $P$-value of $<0.0001$. The $P$-value of 0.05 indicated that the model term was significant. The $F$-value of 110.33 also showed the significance of this model. Meanwhile, the $F$-value of 1.12 from the lack of fit implied the insignificant lack 
of fit, which was relative to pure error as the $P$-value was 0.4416 , which is greater than 0.1000 . No significant lack of fit indicated that this model had good predictability (Bezerra et al. 2008).

The value of coefficient of determination $\left(R^{2}\right)$ was 0.9875 (Table 4 ). $R^{2}$ value closer to linearity indicates good regression. The adjusted $R^{2}(0.9785)$ and predicted
$R^{2}(0.9488)$ values were in reasonable agreement (Hamzaoui et al. 2008). The value of adequate precision greater than 4 is desirable. Adequate precision measures the signal to noise ratio, which in this case, the value of 29.89 was obtained, indicating an adequate ratio. In this study, low coefficient of variation and standard deviation (SD) values were obtained, implying that this model was well developed (García-Gómez et al. 2014).

TABLE 2. Central composite rotatable design (CCRD) for hydrogenation of LNR using RSM method and experimental hydrogenation percentage response data

\begin{tabular}{ccccc}
\hline \multirow{2}{*}{ Run no. } & MSH:LNR weight ratio, $A$ & Reaction time, $B(\mathrm{~min})$ & \multicolumn{2}{c}{ Hydrogenation $(\%)$} \\
\cline { 3 - 4 } 1 & $0.93(+1)$ & $25.86(-1)$ & Actual & Predicted \\
\hline 2 & $0.57(-1)$ & $25.86(-1)$ & 27.14 & 35.69 \\
3 & $1.00(+2)$ & $40.00(0)$ & 41.79 & 26.67 \\
4 & $0.75(0)$ & $40.00(0)$ & 28.93 & 29.86 \\
5 & $0.50(-2)$ & $40.00(0)$ & 29.00 & 29.38 \\
6 & $0.75(0)$ & $40.00(0)$ & 29.43 & 29.86 \\
7 & $0.75(0)$ & $20.00(-2)$ & 28.67 & 29.51 \\
8 & $0.57(-1)$ & $54.14(+1)$ & 35.94 & 36.14 \\
9 & $0.75(0)$ & $40.00(0)$ & 31.08 & 29.86 \\
10 & $0.93(+1)$ & $54.14(+1)$ & 43.91 & 44.48 \\
11 & $0.75(0)$ & $40.00(0)$ & 29.48 & 29.86 \\
12 & $0.75(0)$ & $40.00(0)$ & 30.36 & 29.86 \\
13 & $0.75(0)$ & $60.00(+2)$ & 43.02 & 42.43 \\
\hline
\end{tabular}

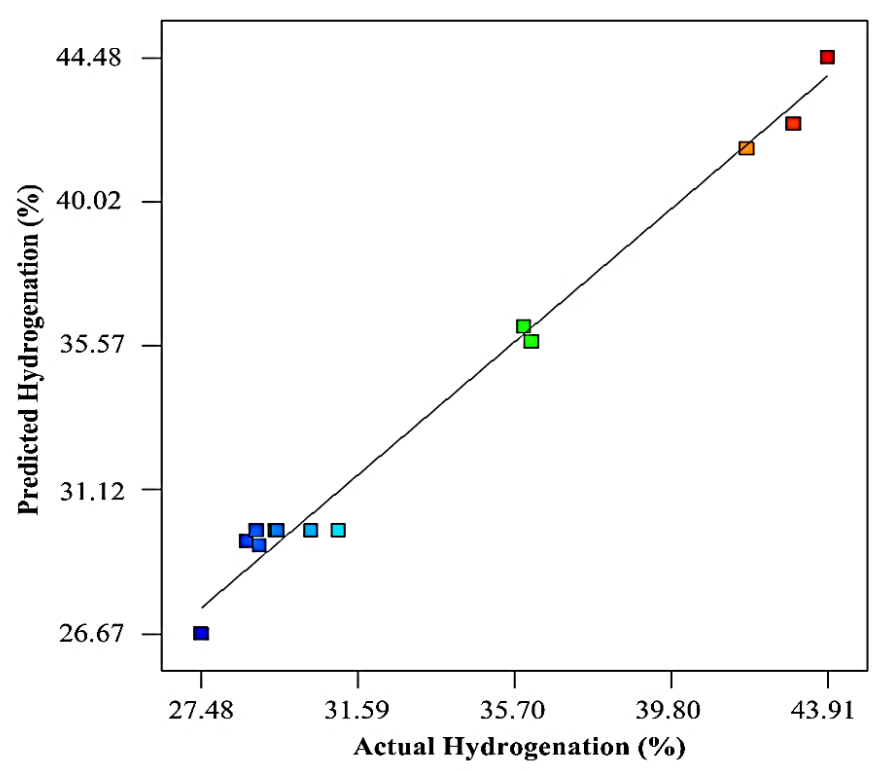

FIGURE 1. Plot of correlation between the predicted and actual experiment values for the hydrogenation percentage 
TABLE 3. ANOVA of the hydrogenation percentage for response surface reduced cubic mode

\begin{tabular}{llcccc}
\hline Source & Sum of squares & $\begin{array}{l}\text { Degree of } \\
\text { freedom }\end{array}$ & Mean square & $F$-value & $P$-value \\
\hline Model & 424.40 & 5 & 84.88 & 110.33 & $<0.0001$ \\
MSH:LNR weight ratio, $A$ & 150.67 & 1 & 150.67 & 195.85 & $<0.0001$ \\
Reaction time, $B$ & 166.75 & 1 & 166.75 & 216.75 & $<0.0001$ \\
$A B$ & 0.12 & 1 & 0.12 & 0.15 & 0.7058 \\
$A^{2}$ & 55.77 & 1 & 55.77 & 72.49 & $<0.0001$ \\
$B^{2}$ & 64.98 & 1 & 64.98 & 84.47 & $<0.0001$ \\
Residual & 5.39 & 7 & 0.77 & - & - \\
Lack-of-fit & 2.45 & 3 & 0.82 & 1.12 & 0.4416 \\
Pure error & 2.93 & 4 & 0.73 & - & - \\
Corrected total & 429.79 & 12 & - & - & - \\
\hline
\end{tabular}

TABLE 4. Statistical parameter of the model equation as obtained from ANOVA model

\begin{tabular}{ll}
\hline Type of variables & Value \\
\hline Standard deviation (SD) & 0.88 \\
Mean & 33.48 \\
Coefficient of variation (C.V.) & 2.62 \\
Press & 22.02 \\
$R^{2}$ & 0.9875 \\
Adjusted $R^{2}$ & 0.9785 \\
Predicted $R^{2}$ & 0.9488 \\
Adequate precision & 29.890 \\
\hline
\end{tabular}

\section{EFFECT OF INTERACTION BETWEEN FACTORS}

On the basis of experiment, the highest hydrogenation percentage will be obtained when the MSH:LNR weight ratio is high. In addition, longer reaction time will lead to much higher hydrogenation percentage. Figure 2 shows the three-dimensional (3D) surface plots of the response surface plots for the hydrogenation percentage. The 3D response surface plots as a function of MSH:LNR weight ratio and the reaction time were interpreted in the range of 0.57-0.93 and 25.86-54.14 min, respectively, with a fixed reaction temperature at $100{ }^{\circ} \mathrm{C}$. The reaction temperature was fixed because it is less contributive for the increment of the hydrogenation percentage as MSH can decompose by thermolysis at $100{ }^{\circ} \mathrm{C}$. Based on 3D surface plots, the hydrogenation percentage increased as MSH:LNR weight ratio increased. MSH:LNR weight ratio plays an important role in the hydrogenation of LNR. Rasid et al. (2016) had conducted an experiment to investigate the effect of MSH:LNR weight ratio on the hydrogenation percentage. It was shown that the hydrogenation percentage had decreased when the ratio increased. This was due to excessive of diimide in the reaction that could 
cause major disproportionation (Miller 1965). However, MSH:LNR weight ratio of 1:1 was the most convenient ratio to get the highest hydrogenation percentage.

Meanwhile, extension of reaction time will lead to higher hydrogenation percentage because the diimide remains in reaction. Once all $\mathrm{MSH}$ are decomposed by thermolysis, hydrogenation cannot be continued due to deficiency of diimide sources. From the results, prolonging the reaction time would be significant in increasing the hydrogenation percentage. It was shown that the reaction time parameter was more important than MSH:LNR weight ratio for hydrogenation of LNR.

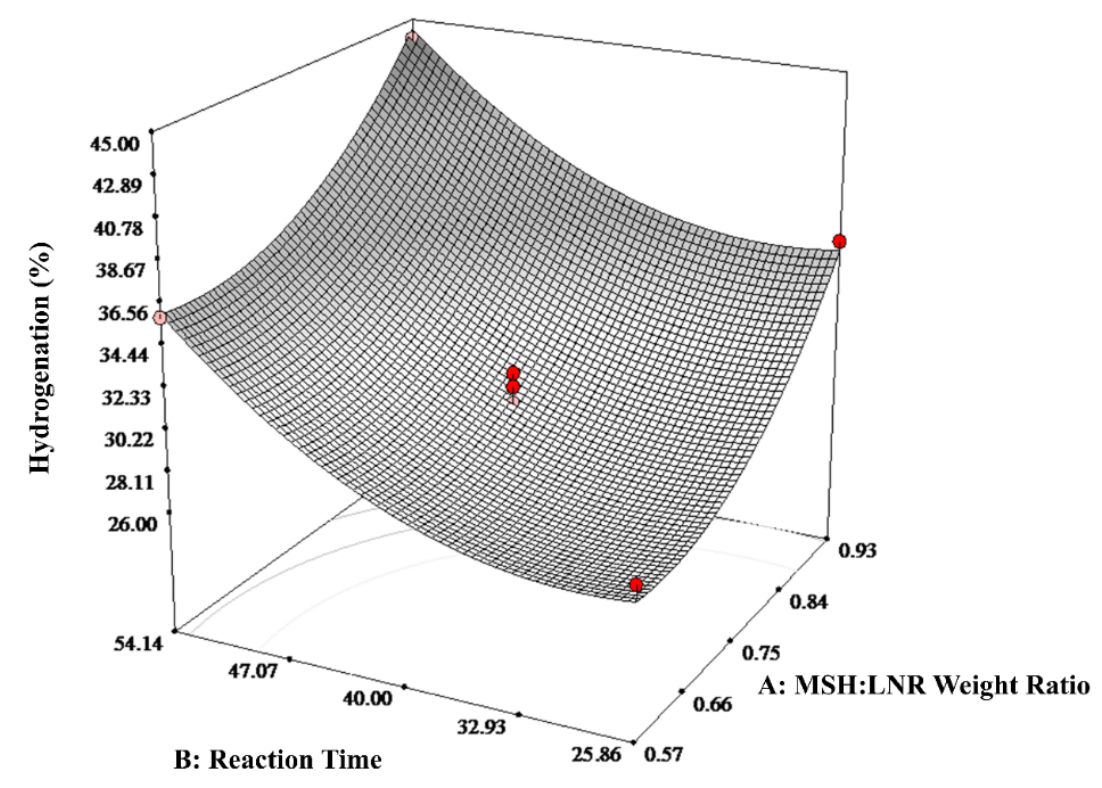

FIGURE 2. 3D surface of hydrogenation percentage as a function of MSH:LNR weight ratio and reaction time

\section{VALIDATION OF MODEL AND OPTIMIZATION OF REACTION}

The optimization process was carried out by optimization function of Design Expert Software. The maximum hydrogenation response was set as the main goal, while the other factors were in the minimum value. The experiment and the response from the optimization of hydrogenation (Table 5) indicated good correspondence based on small differences of predicted and actual values. Validation of the reduced-quadratic model was carried out by performing some sets of experiment with different reaction conditions from CCRD. The validation of results for the model is shown in Table 6. Relationship between the independent variables and the response revealed good correspondence based on the small differences obtained between the predicted and actual values.

TABLE 5. Optimum conditions for the hydrogenation of LNR using MSH as diimide source

\begin{tabular}{lllllll}
\hline \multirow{2}{*}{ Run no. } & MSH:LNR weight ratio, $A$ & Reaction time, $B(\mathrm{~min})$ & \multicolumn{2}{l}{ Hydrogenation $(\%)$} & \\
\cline { 5 - 6 } & & & Actual & \multicolumn{2}{l}{ Predicted } & Deviation \\
\hline 1 & 0.57 & 47.06 & 30.75 & 31.42 & 0.67 \\
\hline
\end{tabular}

TABLE 6. Validation of the quadratic model for optimization of HLNR using MSH via RSM

\begin{tabular}{|c|c|c|c|c|}
\hline \multirow{2}{*}{ MSH:LNR weight ratio, $A$} & \multirow{2}{*}{ Reaction time, $B$ (min) } & \multicolumn{2}{|c|}{ Hydrogenation (\%) } & \multirow{2}{*}{ Difference } \\
\hline & & Actual & Predicted & \\
\hline 0.95 & 57 & 46.35 & 46.04 & 0.31 \\
\hline 0.85 & 45 & 30.56 & 30.36 & 0.20 \\
\hline 0.70 & 50 & 31.32 & 31.47 & 0.15 \\
\hline
\end{tabular}




\section{STRUCTURAL CHARACTERIZATION OF HLNR}

The microstructures of LNR and HLNR were characterized using FTIR and NMR. Figure 3 provides the comparison of FTIR spectra between LNR and HLNR (43.91\%). The analysis on LNR spectrum showed the presence of main absorption bands at $834 \mathrm{~cm}^{-1}, 1664$ $\mathrm{cm}^{-1}$, and $3000-2850 \mathrm{~cm}^{-1}$ that were assigned to olefinic $\mathrm{C}-\mathrm{H}$ bending, $\mathrm{C}=\mathrm{C}$ stretching and $s p^{3} \mathrm{C}-\mathrm{H}$ stretching, respectively. Changes upon hydrogenation were observed by comparing it to LNR. HLNR spectrum showed the obvious change in the intensity of the $s p^{3}$ C-H stretching (3000-2850 $\left.\mathrm{cm}^{-1}\right)$, due to the increment of alkane groups. However, the peak intensity of the olefinic $\mathrm{C}-\mathrm{H}$ bending $\left(834 \mathrm{~cm}^{-1}\right)$ and $\mathrm{C}=\mathrm{C}$ stretching $\left(1664 \mathrm{~cm}^{-1}\right)$ were reduced.
Figure 4 shows the ${ }^{1} \mathrm{H}$ NMR spectra of LNR and HLNR $(43.91 \%)$. The ${ }^{1} \mathrm{H}$ NMR signals of LNR were attributed to olefinic proton (5.12 ppm), unsaturated methylene $(2.02 \mathrm{ppm})$ and methyl groups (1.73 ppm). After hydrogenation, those three signals were reduced. The new proton signals appeared in the range of 0.85 $1.39 \mathrm{ppm}$, which was attributed to methylene $\left(-\mathrm{CH}_{2}-\right)$ and methyl $\left(-\mathrm{CH}_{3}\right)$ groups. The signals around 2.3-2.5 ppm corresponded to benzylic proton from MSH (Rasid et al. 2016). The percentage of hydrogenation was calculated from the integration on NMR spectrum. The percentage of hydrogenation was calculated from the ratio between the integration of the olefinic proton signal and integration of the methyl proton of the saturated unit in the range of 0.60-2.10 ppm (Jamaluddin et al. 2016).

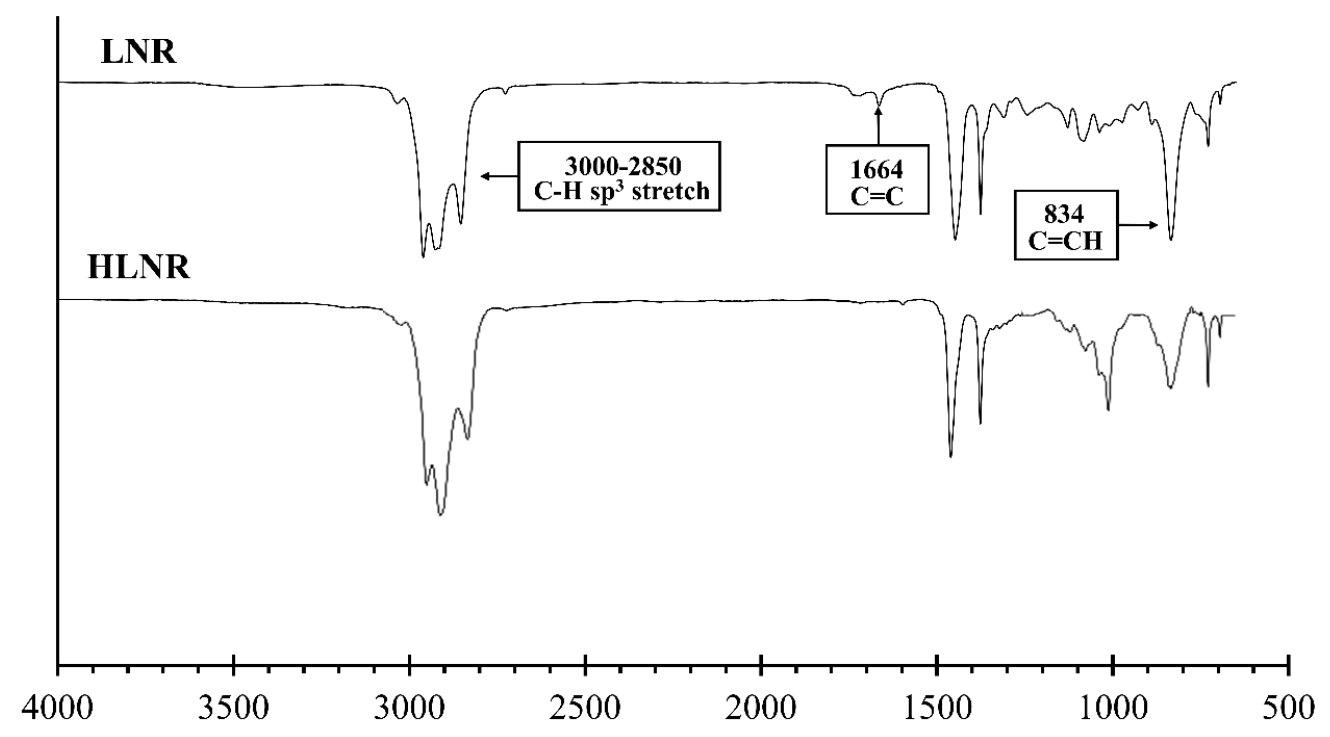

FIGURE 3. FTIR spectra of LNR and HLNR (43.91\%)

\section{MECHANICAL PROPERTIES OF PLA/NR BLENDS}

Mechanical tests such as impact and tensile test were performed to evaluate the effectiveness of LNR and HLNR as PLA/NR compatibilizers. Compositions of $2 \%, 4 \%$ and $6 \%$ were used in this study for each type of compatibilizer used. Table 7 shows the comparison of the tensile strength and impact strength of PLA/NR blend using different compositions of compatibilizer.

Without any compatibilizer, the tensile strength of the PLA/NR was low. Based on Figure 5(a), after the addition of LNR in the PLA/NR blends, the tensile strength was increased from 17.30-20.10 MPa with $6 \%$ LNR content. This might be due to the presence of carbonyl group from PLA that could increase the interaction between mixing materials (Rosli et al. 2016). Meanwhile, PLA/NR with 4\% HLNR content had even higher tensile strength of $23.65 \mathrm{MPa}$. The rigidity of the HLNR structure helped in improving the tensile strength of the blends (Jamaluddin et al. 2016). However, the addition of HLNR by $6 \%$ had lowered the tensile strength to $13.55 \mathrm{MPa}$. The decrease in the tensile strength was probably due to NR particles stacking with HLNR in the PLA/LNR blends, thus increasing the domain size (Rosli et al. 2016). 

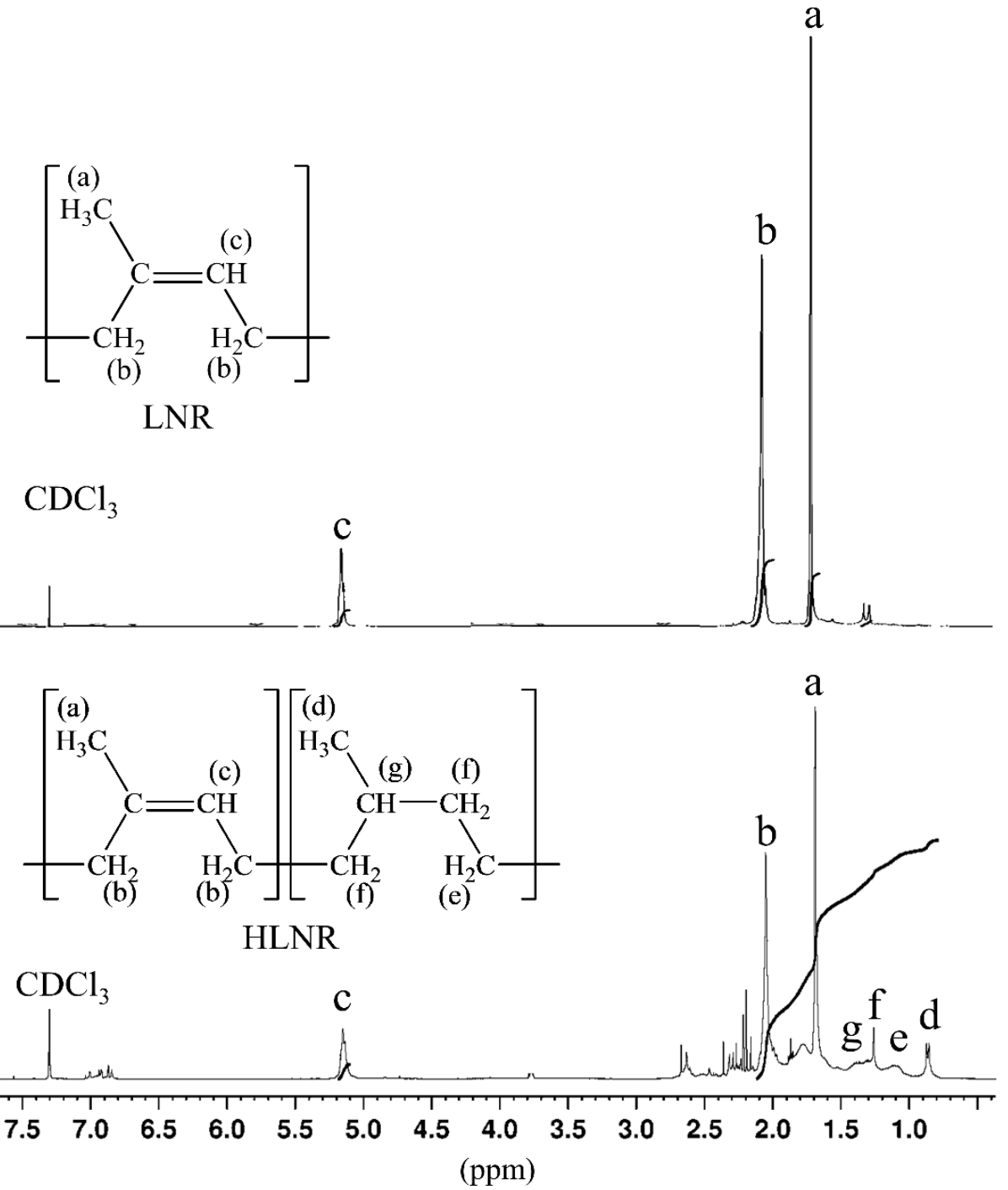

FIGURE 4. ${ }^{1} \mathrm{H}$ NMR spectra of LNR and HLNR (43.91\%)

Based on Figure 5(b), the addition of $2 \%$ to $4 \%$ LNR and HLNR had increased the impact strength of PLA/NR. The addition of $2 \%$ HLNR as an additive in PLA/NR blends showed a drastic increase in impact strength compared to the addition of LNR with the same composition. This shows that the interfacial adhesion of HLNR as a compatibilizer was good due to its rigid structure that was effective in transferring stress during breaking. However, the impact strength in PLA/NR blends were reduced at $6 \%$ for both compatibilizers. The arrangement of multiple NR particles in LNR and HLNR between the PLAs had reduced the impact resistance (Friedrich \& Breuer 2015). It is generally accepted that rubber particle size and interfacial adhesion between blend components take the key role in determining the mechanical performance of a polymer blend. Therefore, the dropped of strength impact above $4 \%$ HLNR was due to the large particle size and weak adhesion between components resulted in poor mechanical properties in the blends.

The addition of HLNR has affected the tensile strength and impact force of the blend. HLNR as a stabilizer helps in increasing the adhesion between the rubber and the PLA phase. Interface tension is reduced and interphase interactions in the matrix are enhanced by compatibilizer (Zolali \& Favis 2017). A homogeneous 
phase distribution (Jose et al. 2016) was obtained when HLNR was used as a compatibilizer which contributed to the improvement of the quality of the resulting PLA/ NR blend.

TABLE 7. Tensile strength and impact strength of PLA/NR blends

\begin{tabular}{lcc}
\hline Sample code (Percentage of materials) & Tensile strength, MPa & Impact strength, $\mathrm{kJ} / \mathrm{m}^{2}$ \\
\hline PLA/NR (90:10) & 17.30 & 2.84 \\
PLA/NR/LNR-2\% (90:9:2) & 18.76 & 5.19 \\
PLA/NR/LNR-4\% (90:6:4) & 19.49 & 9.42 \\
PLA/NR/LNR-6\% (90:4:6) & 20.10 & 6.78 \\
PLA/NR/HLNR-2\% (90:8:2) & 21.91 & 7.52 \\
PLA/NR/HLNR-4\% (90:6:4) & 23.65 & 9.26 \\
PLA/NR/HLNR-6\% (90:4:6) & 13.55 & 4.87 \\
\hline
\end{tabular}

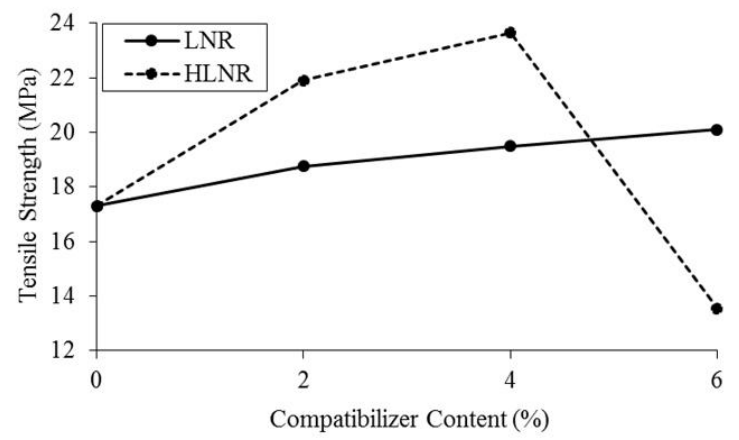

(a)

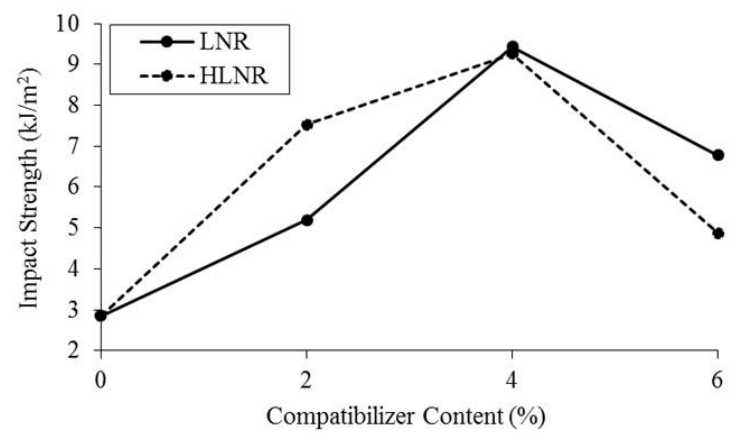

(b)

FIGURE 5. Mechanical properties, as the (a) tensile strength and (b) impact strength of the PLA/NR blends

\section{MORPHOLOGICAL STUDY OF PLA/NR BLENDS}

SEM micrographs of PLA/NR fracture surfaces in Figure 6(a) clearly show a difference in morphology. NR particles were found to be pulled out from the PLA matrix. The incompatibility of polar PLA molecules and the non-polar NR chains showed weak adhesion between them (Ayutthaya \& Poompradub 2014). From Figure 6(b) and Figure 6(c), we can see that the surface of the blends started to flow in one direction, where the particles were well dispersed. The NR particles were widespread due to the addition of LNR and HLNR with composition of $2 \%$. These observations coincided with an increase in the average tensile strength and impact strength that were obtained.
However, the surface roughness of the blend increased as $4 \%$ of compatibilizer was added, as shown in Figure 6(d) and 6(e). The increasing in surface roughness is expected to increase the adhesion between PLA and NR phase (Rosli et al. 2016). Good interfacial adhesion reduced the number of dispersed NR particles, so they remain intact in PLA matrix. This was the main factor for the increase in tensile strength and impact strength. The fracture surfaces of PLA/NR with the addition of HLNR showed that it was effective as combination agents for blends. Addition of HLNR into polymer blends contributes to more uniform particle size distribution (Hong \& Jo 2000). 

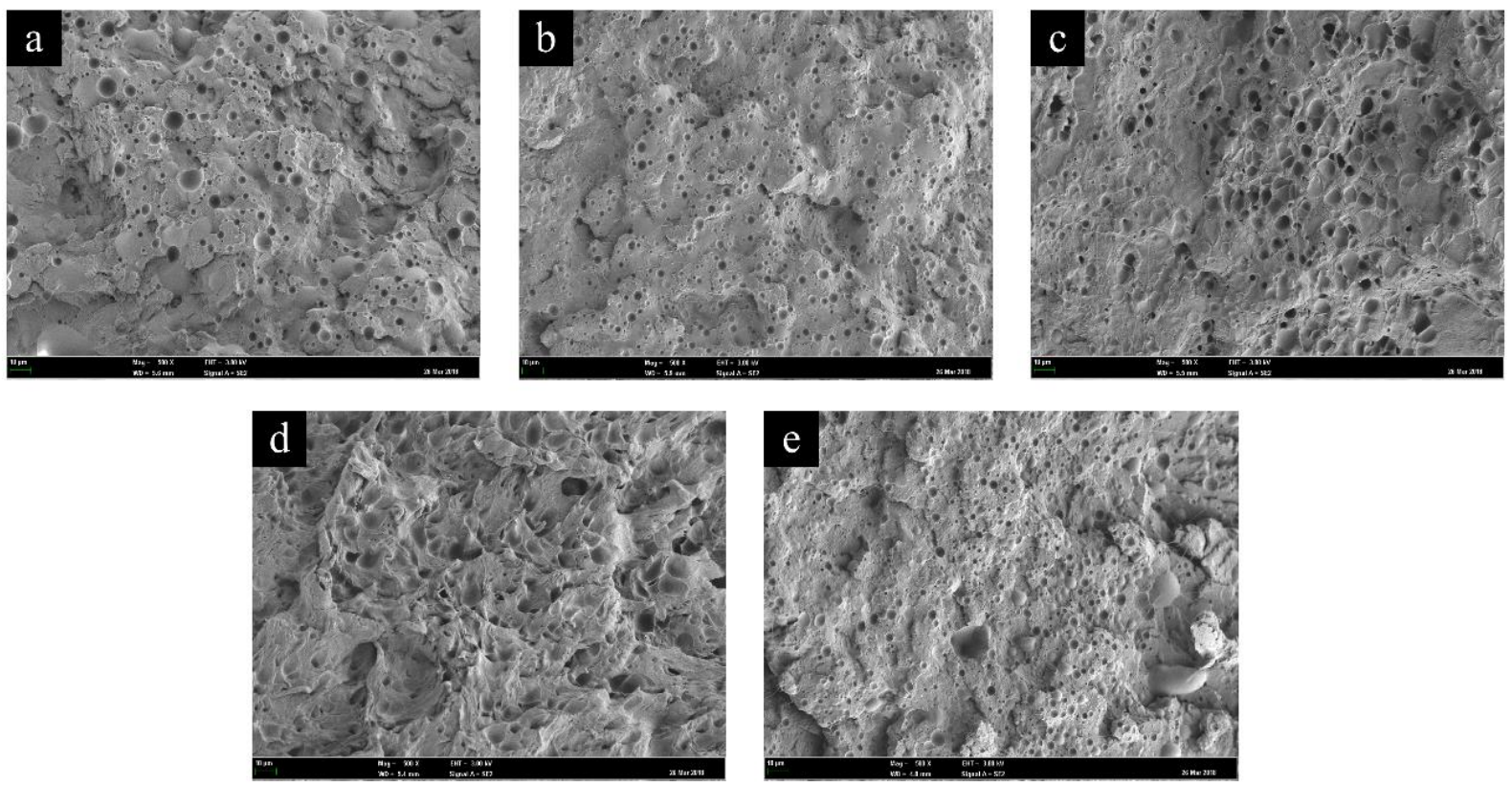

FIGURE 6. Electron microscopy (x1000) of impact fracture surfaces of (a) PLA/NR, (b) PLA/NR/ LNR-2\%, (c) PLA/NR/HLNR-2\%, (d) PLA/NR/LNR-4\% and (e) PLA/NR/HLNR-4\%

\section{CONCLUSION}

Central composite rotatable design/response surface methodology was successfully utilized for the optimization of hydrogenation of LNR using MSH. The effects of two major parameters on hydrogenation were studied and optimized statistically. The reaction time was determined as significant factor compared to MSH:LNR weight ratio. The high coefficient of determination of 0.9875 showed that the predicted and experimental values were well correlated. Based on response surface optimization, the optimum conditions for hydrogenation of LNR using MSH were achieved by MSH:LNR weight ratio of 0.57 and reaction time of 47.06 for $30.75 \%$ of hydrogenation. The optimization and validation of reduced model have shown that this model was reliable to predict hydrogenation percentages with small deviation from the experimental. Other than that, PLA/NR blends with different compositions of LNR and HLNR were prepared. Increased tensile strength and impact strength of the PLA/NR blend was observed. Based on this study, HLNR could also act as compatibilizer to enhance the mechanical properties of PLA/NR blend. The ${ }^{1} \mathrm{H}$ NMR data for all HLNR used to support the findings of this study are included within the article. The mechanical test and SEM data for PLA/NR blends also included within the article.

\section{ACKNOWLEDGEMENTS}

The authors acknowledge the Ministry of Higher Education (MOHE), Malaysia for the research grant (FRGS/1/2020/STG04/UKM/02/2) and Centre for Research and Instrumentation (CRIM) at Universiti Kebangsaan Malaysia (UKM) for their facilities. Also, authors would like to thank Dr Farah Hannan Anuar (FST) for the PLA used in polymer blend studies. The authors declare that there is no conflict of interests regarding the publication of this paper.

\section{REFERENCES}

Abdullah, I. 1996. Process for Manufacturing Liquid Natural Rubber (LNR). Malaysian Patent MY-108852-A.

Ayutthaya, W.D.N. \& Poompradub, S. 2014. Thermal and mechanical properties of poly (lactic acid)/natural rubber blend using epoxidized natural rubber and poly (methyl methacrylate) as co-compatibilizers. Macromolecular Research 22(7): 686-692.

Azhar, N.H.A., Md Rasid, H. \& Yusoff, S.F.M. 2017. Epoxidation and hydroxylation of liquid natural rubber. Sains Malaysiana 46(3): 485-491.

Azhar, N.H.A., Jamaluddin, N., Md Rasid, H., Yusof, M.J.M. \& Yusoff, S.F.M. 2015. Studies on hydrogenation of liquid natural rubber using diimide. International Journal of Polymer Science 2015: Article ID. 243038. 
Bezerra, M.A., Santelli, R.E., Oliveira, E.P., Villar, L.S. \& Escaleira, L.A. 2008. Response surface methodology (RSM) as a tool for optimization in analytical chemistry. Talanta 76(5): 965-977.

Cusack, N.J., Reese, C.B., Risius, A.C. \& Roozepeikar, B. 1976. 2, 4, 6-Tri-isopropylbenzenesulphonyl hydrazide: A convenient source of di-imide. Tetrahedron 32(17): 2157 2162.

Friedrich, K. \& Breuer, U. 2015. Multifunctionality of Polymer Composites: Challenges and New Solutions. William Andrew.

García-Gómez, C., Drogui, P., Zaviska, F., Seyhi, B., GortáresMoroyoqui, P., Buelna, G., Neira-Sáenz, C., Estrada-alvarado, M. \& Ulloa-Mercado, R.G. 2014. Experimental design methodology applied to electrochemical oxidation of carbamazepine using $\mathrm{Ti} / \mathrm{PbO} 2$ and $\mathrm{Ti} / \mathrm{BDD}$ electrodes. Journal of Electroanalytical Chemistry 732: 1-10.

Gunawan, E.R., Basri, M., Rahman, M.B.A., Salleh, A.B. \& Rahman, R.N.Z.A. 2005. Study on response surface methodology (RSM) of lipase-catalyzed synthesis of palmbased wax ester. Enzyme and Microbial Technology 37(7): 739-744.

Hamzah, R., Bakar, M.A., Khairuddean, M., Mohammed, I.A. \& Adnan, R. 2012. A structural study of epoxidized natural rubber (ENR-50) and its cyclic dithiocarbonate derivative using NMR spectroscopy techniques. Molecules 17(9): 10974-10993.

Hamzaoui, A., Jamoussi, B. \& M'nif, A. 2008. Lithium recovery from highly concentrated solutions: Response surface methodology (RSM) process parameters optimization. Hydrometallurgy 90(1): 1-7.

Hong, B.K. \& Jo, W.H. 2000. Effects of molecular weight of SEBS triblock copolymer on the morphology, impact strength, and rheological property of syndiotactic polystyrene/ ethylene-propylene rubber blends. Polymer 41(6): 20692079.

Idris, M.S.F., Wan Mokhtar, W.N.A. \& Yusoff, S.F.M. 2019. New approach on the modification of liquid natural rubber production using microwave technique. Sains Malaysiana 48(7): 1433-1438.

Jamaluddin, N., Yusof, M.J.M., Abdullah, I. \& Yusoff, S.F.M. 2016. Synthesis, characterization, and properties of hydrogenated liquid natural rubber. Rubber Chemistry and Technology 89(2): 227-239.

Jose, S., Parameswaranpillai, J., Francis, B., Aprem, A.S. \& Thomas, S. 2016. Thermal degradation and crystallization characteristics of multiphase polymer systems with and without compatibilizer. Aims Materials Science 3(3): 1177 1198.

Kawahara, S., Kawazura, T., Sawada, T. \& Isono, Y. 2003. Preparation and characterization of natural rubber dispersed in nano-matrix. Polymer 44(16): 4527-4531.

Kongparakul, S., Ng, F.T. \& Rempel, G.L. 2011. Metathesis hydrogenation of natural rubber latex. Applied Catalysis A: General 405(1-2): 129-136.

Mahittikul, A., Prasassarakich, P. \& Rempel, G.L. 2007. Noncatalytic hydrogenation of natural rubber latex. Journal of Applied Polymer Science 103(5): 2885-2895.

Miller, C.E. 1965. Hydrogenation with diimide. Journal of Chemical Education 42(5): 254.
Mohamad, N., Yaakub, J., Abd Razak, J., Yaakob, M.Y., Shueb, M.I. \& Muchtar, A. 2014. Effects of epoxidized natural rubber (ENR-50) and processing parameters on the properties of NR/ EPDM blends using response surface methodology. Journal of Applied Polymer Science 131(17): 40713.

Nor, H.M. \& Ebdon, J.R. 1998. Telechelic liquid natural rubber: A review. Progress in Polymer Science 23(2): 143-177.

Radhakrishnan Nair, M.N., Biju, P.K., Thomas, G.V. \& Gopinathan Nair, M.R. 2009. Blends of PVC and epoxidized liquid natural rubber: Studies on impact modification. Journal of Applied Polymer Science 111(1): 48-56.

Rasid, H.M., Azhar, N.H.A., Jamaluddin, N. \& Yusoff, S.F.M. 2016. Mild approach for non-catalytic hydrogenation of liquid natural rubber using 2, 4, 6-trimethylbenzenesulfonyl hydrazide as the diimide source. Bulletin of the Korean Chemical Society 37(6): 797-801.

Razak, J.A., Ahmad, S.H., Ratnam, C.T., Mahamood, M.A., Yaakub, J. \& Mohamad, N. 2015. Effects of EPDM-g-MAH compatibilizer and internal mixer processing parameters on the properties of NR/EPDM blends: An analysis using response surface methodology. Journal of Applied Polymer Science 132(27): 42199.

Rosli, N.A., Ahmad, I., Anuar, F.H. \& Abdullah, I. 2016. Mechanical and thermal properties of natural rubber-modified poly (lactic acid) compatibilized with telechelic liquid natural rubber. Polymer Testing 54: 196-202.

Sen, S., Mabuni, C. \& Walsh, D. 2001. Development of a methodology for characterizing commercial chlorinated latex gloves. Journal of Applied Polymer Science 82(3): 672-682.

Zhong, J.P., Li, S.D., Wei, Y.C., Peng, Z. \& Yu, H.P. 1999. Study on preparation of chlorinated natural rubber from latex and its thermal stability. Journal of Applied Polymer Science 73(14): 2863-2867.

Zolali, A.M. \& Favis, B.D. 2017. Compatibilization and toughening of co-continuous ternary blends via partially wet droplets at the interface. Polymer 114: 277-288.

Mohamad Shahrul Fizree Idris, Nurfarhana Mohd Mustaffarizan \& Siti Fairus M. Yusoff*

Department of Chemical Sciences

Faculty of Science and Technology

Universiti Kebangsaan Malaysia

43600 UKM Bangi, Selangor Darul Ehsan

Malaysia

Siti Fairus M. Yusoff*

Polymer Research Center (PORCE)

Faculty of Science and Technology

Universiti Kebangsaan Malaysia

43600 UKM Bangi, Selangor Darul Ehsan

Malaysia.

*Corresponding author; email: sitifairus@ukm.edu.my

Received: 12 November 2020

Accepted: 23 February 2021 


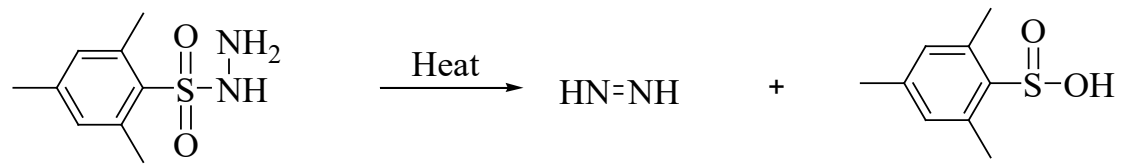

2,4,6-Trimethylbenzenesulfonylhydrazide

Diimide 2,4,6-Trimethylbenzenesulfonic acid

$\mathrm{C}_{3} \mathrm{C}=\mathrm{CH}$
$m \mathrm{CH}_{2} \quad \mathrm{H}_{2} \mathrm{C} m$

LNR
$\mathrm{HN}=\mathrm{NH}$

Diimide

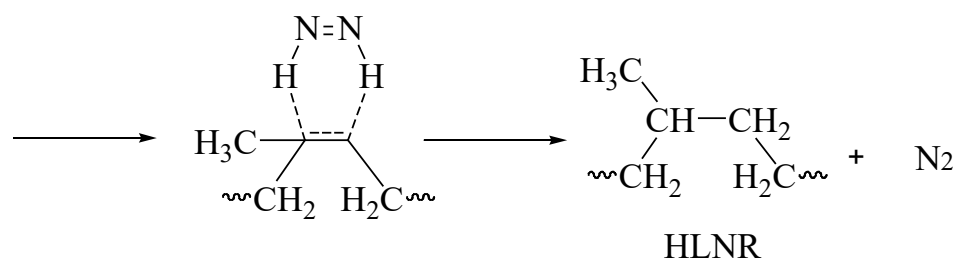

SCHEME 1. Hydrogenation of LNR using MSH 